DOI: https://doi.org/10.24127/ajpm.v8i3.2303

\title{
ETNOMATEMATIKA PADA PERMAINAN DENGKLAQ SEBAGAI MEDIA PEMBELAJARAN MATEMATIKA
}

\author{
Asri Fauzi $^{1}$, Ulfa Lu'luilmaknun ${ }^{2}$ \\ ${ }^{1}$ Pendidikan Guru Sekolah Dasar, Universitas Mataram \\ ${ }^{2}$ Pendidikan Matematika, Universitas Mataram \\ E-mail: $\quad$ asrifauzi@unram.ac.id $^{l)}$ \\ ulfa_l@unram.ac.id $^{2)}$
}

Received 17 September 2019; Received in revised form 6 December 2019; Accepted 24 December 2019

\begin{abstract}
Abstrak
Etnomatematika merupakan strategi pembelajaran dengan mengaitkan unsur budaya dalam pelajaran matematika. Pembelajaran berbasis etnomatematika ini sangat penting untuk menanamkan nilai-nilai karakter sekaligus memupuk rasa cinta anak terhadap budaya lokal yang selama ini sudah mulai ditinggalkan karena kemajuan teknologi. Penelitian ini bertujuan untuk mendeskripsikan unsur-unsur matematika yang terkandung di dalam permainan tradisional dengklaq. Penelitian ini menggunakan jenis penelitian etnografi dengan pendekatan kualitatif. Fokus penelitian ini yaitu arena permainan dengklaq, katuk pemain, aturan bermain, dan pemain dengklaq. Teknik pengumpulan data yang digunakan adalah observasi, wawancara, catatan lapangan, dan dokumentasi. Penelitian ini menggunakan analisis data triangulasi yang terdiri dari reduksi data, penyajian dan penarikan kesimpulan. Hasil penelitian menunjukkan terdapatnya unsur-unsur matematika pada permainan dengklaq berupa geometri bidang, konsep hubungan antar sudut (sudut bertolak belakang, sudut berpelurus, sudut berseberangan), jaringjaring kubus, konsep refleksi, konsep logika matematika, dan konsep peluang.
\end{abstract}

Kata kunci: Etnomatematika; permainan tradisional dengklaq

\begin{abstract}
Ethnomatematics is a learning strategy performed by linking cultural elements in mathematics. Learningbased ethnomatematics is highly important to instil character values as well as fostering children's love for the local culture which has been starting to be abandoned because of technological advances. The study aims to describe the mathematical elements contained in the traditional game of Dengklaq. This research uses ethnographic research with a qualitative approach. The focus of this research is the arena of dengklaq, players'katuk, rules of the games, and dengklaq players themselves. Data collection techniques used were observation, interviews, field notes, and documentation. This research uses triangulation data analysis consisting of data reduction, presentation, and conclusion drawing. The results showed the existence of mathematical elements in the game of dengklaq in the form of field geometry, the concept of relationships between angles (vertical angles, straight angles, alternate angles), cube nets, the concept of reflection, the concept of mathematical logic, and the concept of probability.
\end{abstract}

Keywords: Dengklaq traditional games; ethnomatematics

\section{PENDAHULUAN}

Permainan tradisional adalah aktivitas yang dilakukan tanpa paksaan, mendatangkan rasa kegembiraan dan suasana yang menyenangkan berdasarkan tradisi masing-masing daerah yang ada di lingkungan, dimainkan dengan menggunakan alat ataupun tidak menggunakan alat, dan dilakukan sesuai aturan yang sudah disepakati sebelum permainan dimulai (Widodo \& Lumintuarso, 2017). Permainan tradisional memiliki nilai budaya yang seharusnya dapat dilestarikan dan diketahui oleh anakanak. Selain memiliki nilai budaya, beberapa permainan tradisional juga 
mengandung unsur pembelajaran, termasuk pembelajaran matematika.

Sebuah pendekatan yang dapat digunakan untuk menjelaskan realitas hubungan antara budaya lingkungan dan matematika saat mengajar adalah etnomatematika (Rusliah, 2016). Menurut Irawan dan Kencanawaty (2017), etnomatemtika merupakan unsur budaya yang yang terdapat pembelajaran matematika. Sedangkan menurut Nursyahidah, Saputro dan Rubowo (2018), etnomatematika adalah matematika yang muncul dari aktivitas manusia di lingkungan yang dipengaruhi oleh budaya. Dari beberapa pendapat tentang pengertian etnomatematika, maka dapat disimpulkan bahwa etnomatematika merupakan strategi pembelajaran dengan mengaitkan unsur budaya dalam pelajaran matematika. Etnomatematika sangat sesuai dengan teori konstruktivisme yang membantu siswa untuk meningkatkan pemahaman dan pengetahuan matematika dengan menghubungkan antara mata pelajaran sekolah dengan pengalaman dan pengetahuan mereka sebelumnya (Rosa \& Oray, 2011; Brandt \& Chernoff, 2015).

Indonesia dikenal dengan negara yang memiliki beragam budaya, suku dan bahasa daerah. Indonesia juga memiliki beragam permainan tradisional yang didalamnya memuat unsur-unsur matematika, salah satunya yaitu permainan tradisional dengklaq. Dengklaq (Sunda Manda/Engklek) adalah permainan tradisional yang terdapat di berbagai daerah di Indonesia, termasuk di suku Sasak, Lombok, Nusa Tenggara Barat. Sebutan dengklaq di setiap daerah berbeda, masyarakat suku Sasak biasa menyebut dengan permainan "dengklaq". Dengklaq adalah permainan tradisional yang dimainkan dengan cara melompati petak-petak pada bidang datar dengan satu kaki. Petak-petak yang ada pada permainan dengklaq dapat berbentuk berbagai jenis geometri bidang seperti persegi, segitiga, dan setengah lingkaran. Ini membuktikan bahwa permainan tradisional dengklaq memiliki unsur matematika.

Beberapa penelitian sebelumnya telah membahas mengenai unsur-unsur matematika di dalam permainan tradisional dengkleq Penelitian oleh Muzdalipah dan Yulianto (2015) bertujuan untuk mengungkap potensi etnomatematika pada permainan pecle (dengklaq), yaitu mengandung konsep geometri, simetri lipat dan jaring-jaring bangun. Penelitian yang dilakukan oleh Siregar dan Lestari (2018), membahas tentang unsur-unsur matematika, kegiatan berhitung, menggambar bangun datar dalam permainan dengklaq. Penelitian oleh Aprillia, Trapsilasiwi, Setiawan (2019), membahas etnomatematika pada petak dengklaq yang mengandung unsur bangun datar, refleksi, kekongruenan, jaring-jaring, dan membilang, terdapat pola urutan pemain dengklaq yang memiliki unsur membilang dan peluang, bentuk gaco mengandung unsur bangun datar, serta terdapat unsur logika matematika. Sedangkan pada penelitian ini akan membahas beberapa unsurunsur matematika lainnya yang ada pada permainan dengklaq yang berfokus pada jenis dengklaq ember, dengklaq kasur/sasor, dan dengklaq kapal.

Beberapa penelitian juga membahas mengenai keefektifan permainan tradisional dengklaq dalam pembelajaran matematika, serta manfaatnya untuk membentuk karakter siswa. Penelitian oleh Rahmawati, Buchori, dan Bhihikmah (2017) menunjukkan bahwa permainan 
dengklaq efektif digunakan untuk pembelajaran matematika. Penelitian oleh Fitriyah dan Khaerunisa (2018) menunjukkan bahwa metode drill berbantuan permainan dengklaq termodifikasi berpengaruh terhadap kemampuan pemecahan masalah matematika pada siswa SMP. Penelitian oleh Rusnilawati, Muthmainnah, Mufti, Istiqomah, Ulima, dan Hidayati (2018) menunjukkan bahwa metode pembelajaran permainan tradisional dengklaq berpengaruh positif terhadap motivasi belajar siswa SD. Penelitian oleh Nugraha, Handoyo, dan Sulistyorini (2018) menunjukkan bahwa ada pengaruh pembelajaran berbasis permainan tradisional terhadap keterampilan sosial siswa SD. Penelitian oleh Kawuryan, Hastuti, dan Supartinah (2018) menunjukkan bahwa model pembelajaran tematik berbasis permainan tradisional dan berorientasi scientific approach terbukti positif dan signifikan berpengaruh terhadap kemampuan berpikir kreatif siswa SD. Penelitian oleh Imswatama dan Lukman (2018) menunjukkan bahwa bahan ajar matematika berbasis etnomatematika terbukti efektif dalam pemecahan keterampilan masalah dan berpikir kritis matematis siswa SMP.

Pada abad 21 saat ini atau yang dikenal dengan era globalisasi, kegiatan manusia tidak bisa terlepas dari pemanfaatan teknologi. Smartphone adalah salah satu pemanfaatan teknologi yang sering digunakan, tidak hanya oleh kalangan dewasa tetapi juga oleh kalangan anak-anak. Anak-anak biasanya menggunakan smartphone untuk mengakses internet dan bermain game. Banyak anak-anak menghabiskan waktu luang untuk bermain game smartphone di dalam rumah sehingga kesempatan untuk bersosialisasi bersama teman di luar rumah menjadi semakin rendah. Permainan modern yang ada di smartphone menjadi lebih menarik dibandingkan permainan tradisional, akibatnya permainan tradisional sudah jarang dimainkan oleh anak-anak.

Pembelajaran matematika di sekolah saat ini, masih banyak dilakukan di dalam kelas. Terkadang siswa butuh untuk menumbuhkan kreatifitasnya dengan cara belajar matematika di luar kelas. Salah satu media pembelajaran yang dapat digunakan untuk belajar matematika di luar kelas yaitu melalui permainan tradisional dengklaq. Belajar melalui permainan tradisional juga dapat mengenalkan siswa tentang budaya mereka.

Berdasarkan latar belakang dan beberapa penelitian sebelumnya yang sudah uraikan, dapat disimpulkan bahwa permainan tradisional dengklaq terbukti memiliki unsur-unsur matematika. Permainan tradisional dengklaq juga efektif digunakan dalam pembelajaran matematika. Oleh karena itu, penelitian ini bertujuan untuk mendeskripsikan unsur-unsur matematika yang terkandung di dalam permainan tradisional dengklaq dan melengkapi kajian dari penelitian sebelumnya.

\section{METODE PENELITIAN}

Dalam penelitian menggunakan jenis penelitian etnografi dengan pendekatan kualitatif. Sejalan dengan hal itu, penelitian ini mendeskripsikan mengenai apa saja unsur-unsur matematika yang terkandung dalam permainan tradisional dengklaq, sehingga fokus penelitian ini terfokus pada permainan tradisional masyarakat sasak yaitu permainan dengklaq yang terdiri dari arena permainan dengklaq, 
dadu atau yang disebut dengan katuk oleh masyarakat sasak, aturan bermain, dan pemain dengklaq.

Teknik pengumpulan data yang digunakan yaitu observasi, wawancara, catatan lapangan, dan dokumentasi. Subjek penelitian ini adalah tiga jenis permainan dengklaq yaitu dengklaq ember, dengklaq Kasur/sasor, dan dengklaq kapal. Dalam penelitian ini yang menjadi narasumber dalam wawancara untuk memperoleh informasi mengenai unsur yang terkandung dalam permainan tradisional sasak dengklaq adalah 1 orang dosen Pendidikan matematika dan 1 orang dosen seni budaya daerah.

Analisis data yang digunakan dalam penelitian ini adalah triangulasi yaitu reduksi data, penyajian dan penarikan kesimpulan. Reduksi data merupakan suatu bentuk analisis yang menajamkan, menggongkan, mengarahkan, dan membuang yang tidak perlu. Dalam penelitian ini, hasil pengumpulan data yang dilakukan melalui wawancara, observasi, dan dokumentasi tentang permainan tradisional dengklaq direduksi dengan memilih informasi-informasi yang dibutuhkan dalam penelitian ini. Hasil reduksi data didapatkan unsur yang terdapat dalam permainan dengklaq ini adalah unsur geometri, jaring-jaring kubus, hubungan antar sudut, refleksi atau pencerminan, dan konsep peluang. Kemudian setelah direduksi, tahap selanjutnya adalah penyajian data dimana dalam penelitian ini hasil reduksi data disajikan dengan menggambarkan sketsa arena permainan dengklaq dan kemudian dijelaskan unsur matematika yang terdapat di dalamnya. Setelah melakukan reduksi dan penyajian data dilakukan penarikan kesimpulan untuk mengetahui apa saja unsur-unsur matematika yang terdapat pada permainan dengklaq baik dari arena permainan, katuk para pemain, aturan bermain, maupun pemain dengklaq itu sendiri.

\section{HASIL PENELITIAN DAN PEMBAHASAN}

Permainan dengklaq merupakan salah satu permainan tradisional masyarakat sasak yang sangat digemari oleh anak-anak terutama pada anak usia 7 tahun sampai 15 tahun. Permainan dengklaq ini memiliki sistem permainan yang sederhana, dimana yang menjadi pemain dalam permainan dengklaq berjumlah dua sampai lima orang. Masyarakat sasak menggemari permainan ini tidak hanya sebagai hiburan tetapi terdapat nilai edukasi yang terkandung di dalam permainan dengklaq tersebut. Dalam permainan ini menggambarkan perjuangan seseorang dalam memperebutkan daerah kekuasaannya dengan aturan-aturan bermain yang sudah disepakati bersama.

Aturan permainannya sederhana yaitu (1) pemain harus menggunakan satu kaki untuk berpijak disetiap petakan di arena bermain; (2) pemain tidak boleh menginjak garis pada arena bermain; (3) katuk yang dilemparkan harus jatuh tepat pada petakan yang dituju. Jika katuk yang dilemparkan berada pada garis arena atau petakan yang bukan dituju maka pemain dinyatakan kalah; (4) pemain tidak boleh menginjakkan kaki pada petakan yang berisi katuk lawan; (5) Semua petakan pada arena harus pernah diisi oleh katuk pemain; (6) pemain tidak boleh menginjakkan kaki pada daerah kekuasaan yang sudah didapatkan oleh lawan; (7) permainan dinyatakan selesai jika semua petakan pada arena dengklaq menjadi daerah kekuasaan pemain; (8) pemain yang mempunyai daerah 
kekuasaan paling banyak maka dinyatakan sebagai pemenang.

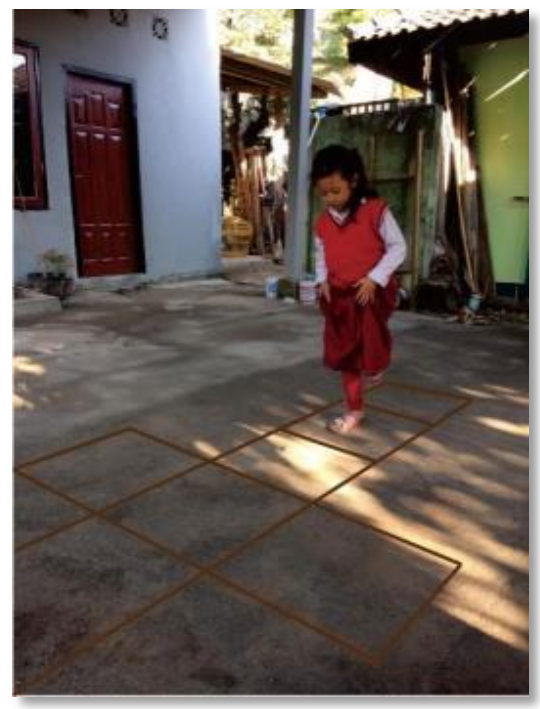

Gambar 1. Permainan Dengklaq.

Gambar 1 merupakan salah satu jenis permainan dengklaq yang banyak dimainkan oleh anak-anak. Langkahlangkah dalam permainan dengklek yaitu (1) para pemain membuat arena dengklaq pada tanah; (2) setiap pemain harus mempunyai katuk yang terbuat dari pecahan genting atau keramik dan diletakkan pada petak pertama arena dengklaq; (3) pemain melakukan hompimpa untuk menentukan urutan bermain; (4) pemain urutan pertama mulai melakukan pijakan menggunakan satu kaki dari petakan kedua sampai petakan terakhir dan kembali lagi untuk mengambil katuk yang terdapat pada petakan pertama; (5) pemain urutan pertama melemparkan katuknya ke petakan yang kedua, kemudian melanjutkan pijakannya sampai petakan terakhir dan kembali lagi mengambil katuknya ke luar arena bermain; (6) hal tersebut dilakukan secara terus menerus sampai semua petakan sudah pernah diisi oleh katuk pemain yang mempunyai giliran, dan pemain tidak boleh menginjakkan kaki pada petakan yang terisi katuk; (7) pergantian pemain urutan kedua, jika pemain urutan pertama melakukan kesalahan dengan menginjak garis arena bermain ataupun katuk yang dilemparkannya tidak tepat sasaran; (8) pemain urutan kedua melakukan langkah-langkah seperti pemain urutan pertama sampai melakukan kesalahan dan berganti giliran untuk pemain urutan ketiga sampai pemain urutan terakhir; (9) setelah semua petakan pada arena bermain dengklaq diisi oleh katuk pemain, maka pemain diberi kesempatan untuk mencarian daerah kekuasaan; (10) untuk mencari daerah kekuasaan, pemain membelakangi arena bermain kemudian melemparkan katuknya pada arena, sehingga petakan tempat jatuhnya katuk pemain menjadi daerah kekuasaannya; (11) daerah kekuasaan yang dimenangkan oleh pemain, maka pemain lain tidak boleh menginjak petakan tersebut selama permainan berlangsung; (12) pemain yang memperoleh daerah kekuasaan dinyatakan menang.

Permainan dengklaq ini secara tidak langsung akan membentuk karakter anak karena dalam permainan ini mengandung banyak manfaat bagi perkembangan anak. Manfaat yang bisa diambil dari permainan ini adalah melatih fisik dan keseimbangan anak ketika melakukan pijakan dengan satu kaki, melatih konsentrasi anak ketika melemparkan katuk pada petak yang dituju, melatih kecerdasan anak karena dalam permainan dilatih untuk berhitung langkah demi langkah yang harus dilewati, melatih anak untuk menaati aturan, melatih anak untuk bersosialisasi dengan temannya dan melatih kreativitas anak. Hal ini sejalan dengan yang diungkapkan oleh Dharmamulya (2008) bahwa terdapat nilai-nilai budaya dalam permainan tradisional seperti nilai kejujuran, nilai 
kepemimpinan, nilai kebersamaan, menumbuhkan rasa tanggung jawab serta melatih anak dalam kecakapan berhitung, berpikir dan berlogika.

Selain membentuk karakter siswa, permainan dengklaq memiliki unsurunsur matematika. Unsur-unsur matematika dari hasil eksplorasi pada permainan dengklaq tersebut ditemukan unsur geometri bidang, hubungan antar sudut, jaring-jaring, kekongruenan, refleksi, logika matematika, dan konsep probabilitas atau peluang. Berikut ini pembahasan unsur-unsur matematika berdasarkan objek yang difokuskan oleh peneliti yaitu pada arena permainan, katuk pemain, aturan bermain, dan pemain dengklaq.

1. Arena Permainan Dengklaq

Pada dasarnya jenis permainan tradisional dengklaq memiliki berbagai macam jenis. Namun yang sering dimainkan oleh anak-anak pada masyarakat sasak ada tiga jenis, yaitu dengklaq ember, dengklaq kasur/sasor, dan dengklaq kapal. Sketsa dari masingmasing jenis dengklaq dapat dilihat pada Gambar 2.
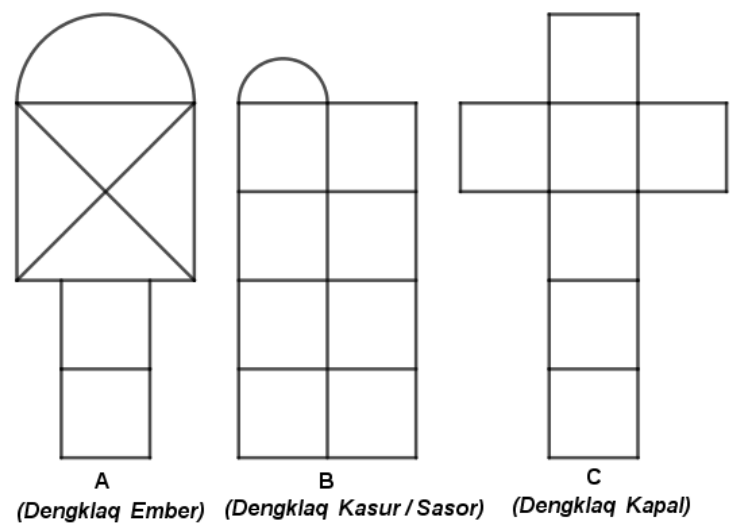

Gambar 2. Sketsa arena dengklaq.

Berdasarkan hasil penelitian dan eksplorasi terhadap arena permainan dengklaq ditemukan beberapa unsur matematika yaitu terdapatnya unsur geometri bidang, hubungan antar sudut, jaring-jaring, kekongruenan, dan refleksi. Unsur matematika berupa konsep geometri bidang dan konsep hubungan antar sudut disajikan pada Gambar 3.

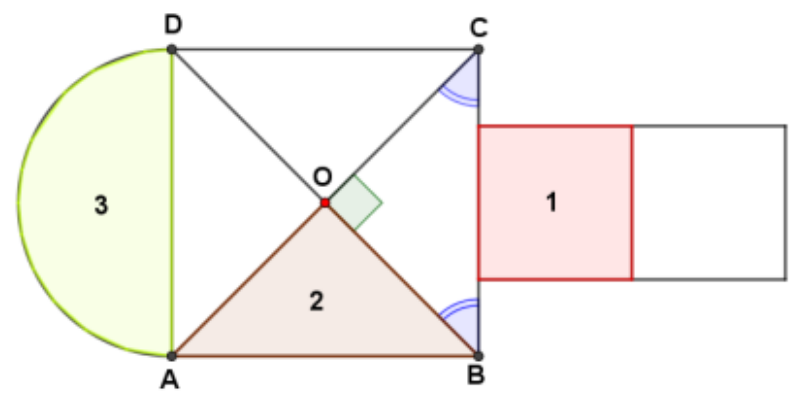

Gambar 3. Konsep geometri bidang pada arena permainan dengklaq.

Pada Gambar 3 terdapat tiga unsur bidang yang membentuk petakan pada arena permainan dengklaq yaitu persegi, segitiga, dan setengah lingkaran. Jika diperhatikan persegi ABCD jika ditarik kedua diagonalnya yaitu diagonal $\mathrm{AC}$ 
dan BD akan membentuk empat buah segitiga siku-siku sama kaki dimana titik O merupakan penyiku dari keempat segitiga tersebut. Pada segitiga sikusiku sama kaki dapat diketahui besaran sudut yang terbentuk. Misalkan pada segitiga BOC, karena siku-siku di titik O maka besar $\angle B O C=90^{\circ}$ dan besar $\angle O B C=$ besar $\angle O C B=45^{\circ}$. Selanjutnya unsur matematika lainnya yaitu konsep hubungan antar sudut.

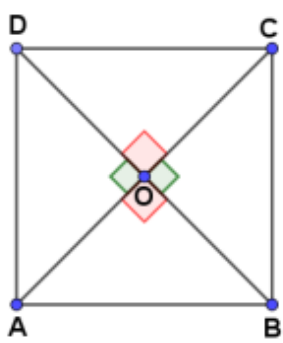

(a)
Konsep hubungan antar sudut yang terjadi adalah konsep sudut yang bertolak belakang, konsep sudut berpelurus, dan sudut berseberangan. Gambar 4 menyajikan ilustrasi petakan arena permainan dengklaq yang mengandung unsur konsep hubungan antar sudut.

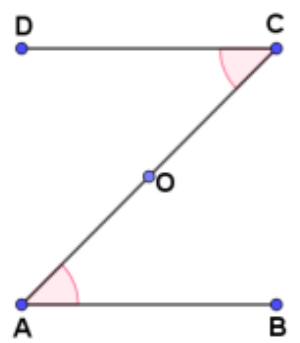

(b)

Gambar 4. Ilustrasi konsep hubungan antar sudut.

Gambar 4 menyajikan ilustrasi konsep sudut bertolak belakang dan berpelurus (lihat Gambar 4a), dan konsep sudut berseberangan (lihat Gambar 4b) yang terdapat pada petakan arena permainan dengklaq. Jika diperhatikan Gambar 4a, sudut yang bertolak belakang pada ilustrasi tersebut adalah $\angle A O B$ dengan $\angle C O D$ dan $\angle A O D$ dengan $\angle B O C$. Karena besar $\angle A O B=$ besar $\angle C O D=90^{\circ}$ dan besar $\angle A O D=$ besar $\angle B O C=90^{\circ}$ maka dapat disimpulkan bahwa sudut yang bertolak belakang sama besar. Sedangkan sudut yang berpelurus yaitu $\angle A O B$ berpelurus dengan $\angle B O C$ dan $\angle B O C$ berpelurus dengan $\angle C O D$. Dari ilustrasi tersebut dapat kita ketahui bahwa jumlah besar sudut yang berpelurus adalah $180^{\circ}$. Selanjutnya pada Gambar 4b menyajikan konsep sudut berseberangan dimana $\angle B A O$ berseberangan dengan $\angle D C O$. Karena besar $\angle B A O=$ besar $\angle D C O=45^{\circ}$, maka dapat kita simpulkan bahwa sudut-sudut yang berseberangan memiliki besar sudut yang sama.

Unsur matematika selanjutnya yang terdapat pada arena permainan dengklaq adalah jarring-jaring. Jika diperhatikan petak dengklaq membentuk jarring-jaring kubus. Ilustrasi jaring-jaring kubus pada arena permainan dengklaq disajikan pada Gambar 5. 
DOI: https://doi.org/10.24127/ajpm.v8i3.2303
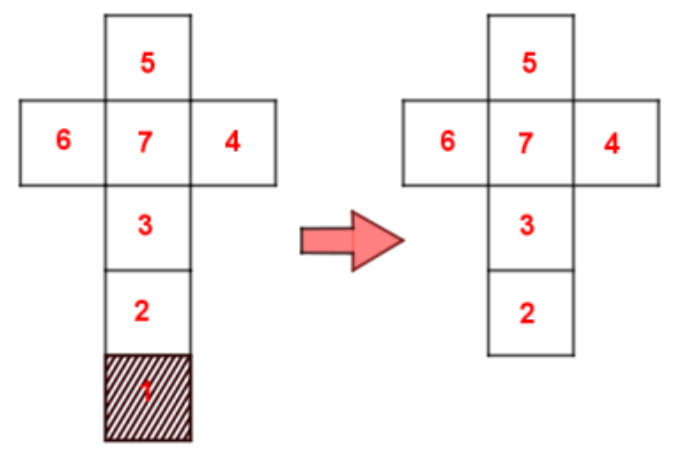

Gambar 5. Jaring-jaring kubus pada arena dengklaq.

Gambar 5 menyajikan bentuk jaring-jaring kubus. Ketika memualai permainan, katuk masing-masing pemain diletakkan pada petakan pertama yaitu daerah yang diarsir pada gambar. Dalam aturan permainan, petakan yang berisi katuk tidak boleh dipijak oleh pemain, sehingga petakan yang boleh dipijak oleh pemain adalah

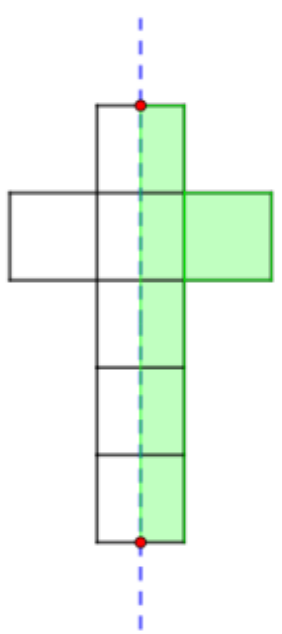

petakan kedua sampai ketujuh, sehingga petakan yang boleh dipijak oleh pemain akan membentuk sebuah jarring-jaring kubus. Selanjutnya, konsep kekongruenan juga terjadi pada petakan arena dengklaq. Hal ini dapat dilihat dari bentuk-bentuk petakan yang sama yaitu berbentuk persegi.

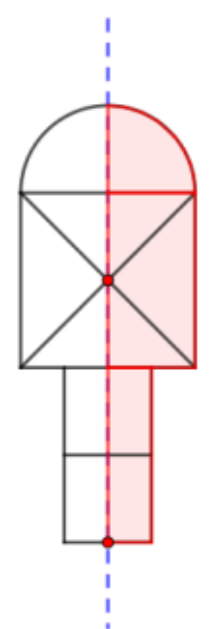

Gambar 6. Ilustrasi konsep refleksi pada arena dengklaq.

Unsur matematika yang terkandung dalam arena permainan dengklaq selanjutnya adalah konsep refleksi atau pencerminan. Arena permainan dengklaq memiliki unsur matematika yaitu pencerminan atau refleksi. Sejalan dengan penelitian oleh Aprilia, Trapsilasiwi, dan Setiawan (2019) yang membahas tentang terdapatnya unsur pencerminan pada dengklaq kapal. Pada penelitian ini ditunjukkan bahwa jenis dengklaq lainnya yang memiliki unsur pencerminan yaitu dengklaq ember. Gambar 6 menyajikan ilustrasi refleksi yang terdapat pada arena permainan dengklaq kapal dan ember. Jika ditarik garis sumbu simetrinya maka akan memotong bagian arena permainan menjadi 2 bagian yang sama yaitu bagian kanan dan bagian kiri. Bagian kanan simetri dengan bagian kiri pada 
permainan dengklaq, sehingga dapat dikatakan bahwa bagian kanan merupakan hasil pencerminan dari bagian kiri arena permainan tradisional dengklaq.

\section{Katuk yang digunakan Pemain}

Katuk merupakan bagian dari permainan dengklaq yang digunakan sebagai alat untuk bermain yang biasanya dibuat dari pecahan genting atau pecahan keramik. Dalam pemilihan katuk, pemain mencari katuk yang bentuknya gepeng sehingga jika dilemparkan pada petakan pada arena permainan dengklaq tidak katuk pemain tidak menggelinding dan jatuh tepat pada petakan yang dituju. Dari hasil penelitian, bentuk katuk mengandung unsur geometri bidang datar. Penelitian ini sejalan dengan penelitian oleh Aprilia, Trapsilasiwi, dan Setiawan (2019). Hal ini dapat dilihat dari bentuk katuk yang berbentuk persegi, segitiga, lingkaran, trapesium. Bentuk katuk yang mengandung unsur bidang datar disajikan pada Gambar 7. Siswa dapat mempelajari bangun datar secara kontekstual dan lebih mudah dengan memanfaatkan katuk dari permainan dengklaq.
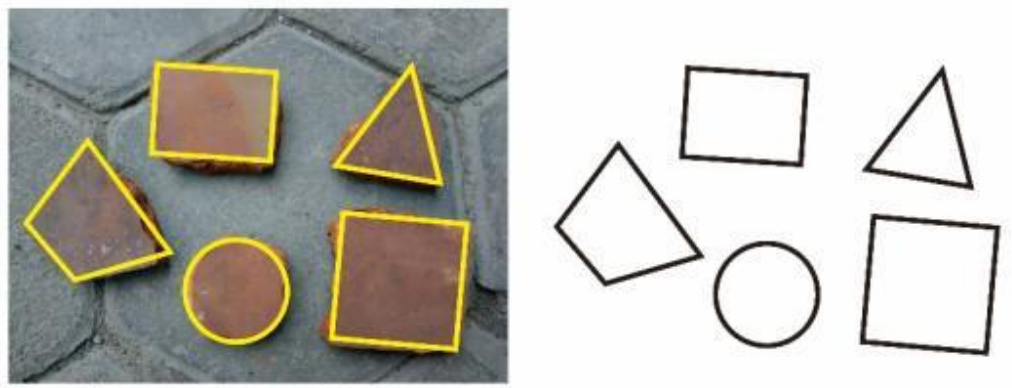

Gambar 7. Unsur geometri bidang pada katuk.

\section{Aturan Bermain}

Dari hasil penelitian dan melengkapi contoh dari penelitian oleh Aprilia, Trapsilasiwi, dan Setiawan (2019), aturan dalam permainan dengklaq memiliki unsur logika matematika. Misalnya, diambil kaidah implikasi untuk menentukan lanjut atau matinya pemain dalam. Contoh sederhana, diberikan dua pernyataan aturan permainan dengklaq yaitu:

$p=$ Fauzi melemparkan katuknya tidak tepat pada petakan yang dituju.

$q=$ Fauzi tidak bisa melanjutkan permainan sehingga digantikan oleh pemain lain.

Implikasi dari kedua pernyataan tersebut adalah $p \rightarrow q=$ jika Fauzi melemparkan katuknya tidak tepat pada petakan yang dituju maka Fauzi tidak bisa melanjutkan permainan sehingga digantikan oleh pemain lain. Contoh lain, diberikan dua pernyataan berikut: $q=$ Ulfa memiliki daerah kekuasaan terbanyak

$r=$ Ulfa memenangkan permainan dengklaq

Dari pernyataan di atas, maka implikasinya adalah $q \rightarrow r=$ jika Ulfa memiliki daerah kekuasaan terbanyak maka Ulfa memenangkan permainan dengklaq.

\section{Pemain Dengklaq}

Selanjutnya para pemain permainan dengklaq juga mempunyai unsur matematika. Unsur matematika yang terdapat pada pemain dengklaq adalah konsep probabilitas atau peluang. Dalam hal ini dicontohkan 
konsep peluang mendapatkan daerah kekuasaan. Ketika salah satu pemain lebih dulu menyelesaikan misi putaran pertama pada permainan dengklaq, pemain berhak untuk mendapat satu daerah kekuasaan. Jika memakai jenis dengklaq kapal dan ember yang memiliki 7 petak maka peluang pemain mendapatkan daerah kekuasaan yaitu 1:7 atau $\frac{1}{7}$ (satu banding tujuh).

Sedangkan jika memakai jenis dengklaq kasur yang memiliki 9 petak maka peluang pemain mendapatkan daerah kekuasaan yaitu 1:9 atau $\frac{1}{9} \quad$ (satu banding sembilan).

Sejalan dengan penelitian oleh Aprilia, Trapsilasiwi, dan Setiawan (2019), permainan dengklaq memiliki konsep probabilitas atau peluang. Contohnya digunakan untuk menentukan pola urutan bermain. Misalkan terdapat 5 anak yang ingin bermain dengklaq yaitu Denis, Wan, Aprisal, Fauzi, dan Bayu, kemudian kelima anak tersebut melakukan hompimpa untuk menentukan siapa yang akan bermain pertama, kedua, ketiga, keempat, dan kelima. Dengan menggunakan permutasi dapat ditentukan banyaknya pola urutan bermain yang terjadi.

$$
\begin{aligned}
& P(n, n)=\frac{n !}{(n-n) !}=\frac{n !}{0 !}=n ! \\
& P(5,5)=\frac{5 !}{(5-5) !}=\frac{5 !}{0 !}=5 !=5 \times 4 \times 3 \times 2 \times 1=120
\end{aligned}
$$

Karena yang bermain 5 anak maka banyaknya pola urutan yang terjadi adalah sebanyak 120 pola urutan untuk bermain dengklaq dari kelima anak tersebut.

Dalam penelitian Febriyanti, Prasetya, dan Irawan (2018) mengatakan bahwa selain hasil penelitian terdapat unsur matematika, yang tidak kalah pentingnya adalah terdapatnya unsur pendidikan karakter berupa kejujuran, kebersamaan, dan sportivitas yang tinggi dalam melakukan permainan tradisional. Selanjutnya penelitian eksperimen yang dilakukan oleh Damayanti dan Putranti (2016) dengan menggunakan permainan tradisional dengklaq menunjukkan bahwa hasil belajar matematika siswa dapat meningkat, dan respon siswa terhadap pembelajaran matematika dengan permainan sangat menyenangkan dan semakin tertarik untuk belajar matematika.

\section{KESIMPULAN DAN SARAN}

Berdasarkan hasil penelitian ini menunjukkan bahwa permainan tradisional dengklaq tidak hanya sebagai hiburan bagi anak-anak, tetapi juga dalam permainan ini terdapat nilai edukasi yang dapat membentuk karakter anak. Kemudian manfaat yang bisa diambil dari permainan ini adalah dapat melatih fisik dan keseimbangan anak, melatih konsentrasi anak melatih kecerdasan anak, melatih anak untuk mentaati aturan, melatih sportivitas, melatih, kejujuran dan melatih kreativitas anak. Selain bermanfaat bagi anak, permainan dengklaq ini dapat dijadikan sebagai media dalam pembelajaran matematika karena di dalam permainan banyak mengandung unsur matematika. Unsur matematika yang terkandung di dalam permainan tradisional ini berupa konsep geometri bidang yang terdapat pada arena permainan dengklaq dan katuk yang digunakan oleh pemain, konsep kesebangunan, kekongruenan, jaringjaring kubus dan konsep refleksi atau pencerminan pada arena permainan, konsep logika matematika yang terdapat 
pada aturan permainan, dan konsep probabilitas yang terdapat pada pemain dengklaq.

\begin{tabular}{lrr}
\multicolumn{2}{c}{ Pembelajaran } & berbasis \\
etnomatematika sangat & penting \\
diterapkan di sekolah. Hal & tersebut \\
secara tidak langsung & dapat
\end{tabular}
menanamkan nilai-nilai cinta terhadap budaya pada anak. Oleh karena itu, disarankan untuk melakukan penelitian tentang etnomatematika pada permainan tradisional lainnya. Tidak hanya permainan, namun bisa menggunakan unsur-unsur budaya lain untuk dijadikan sebagai media pembelajaran matematika.

\section{DAFTAR PUSTAKA}

Aprilia, E.D., Trapsilasiwa, D., \& Setiawan, T.B. (2019) Etnomatematika dalam permainan engkleq beserta alatnya sebagai bahan ajar. Jurnal Kadikma, 10(1), 85-94.

Brandt, A., \& Chernoff, E. J. (2015). The importance of ethnomathematics in math class. Ohio Journal of School Mathematics, 71, 31-36.

Damayanti, A.D.M., \& Putranti, R.D. (2016). Pembelajaran matematika dalam permainan tradisional engklek untuk siswa SD kelas V. Prosiding Seminar Nasional Matematika dan Terapannya, (pp. 254-260)

Febriyanti, C., Prasetya, R., \& Irawan, A.. (2018). Etnomatematika pada permainan tradisional engkleq dan gasing khas kebudayaan Sunda. Jurnal Ilmu Matematika dan Terapan, 12(1), 1-6.

Fitriyah, A., \& Khaerunisa, I. (2018). Pengaruh penggunaan metode drill berbantuan permainan engklek termodifikasi terhadap kemampuan pemecahan masalah siswa kelas VII. Journal of Medives: Journal of Mathematics Education IKIP Veteran Semarang, 2(2), 167277.

Imswatama, A., \& Lukman, H. S. (2018). The effectiveness of mathematics teaching material based on ethnomathematics. International Journal of Trends in Mathematics Education Research, 1(1), 35-38.

Irawan, A., \& Kencanawaty, G. (2017). Implementasi pembelajaran matematika realistik berbasis etnomatematika. Journal of Medives: Journal of Mathematics Education IKIP Veteran Semarang, 1(2), 74-81.

Kawuryan, S. P., Hastuti, W. S., \& Supartinah. (2018). Pengaruh model pembelajaran tematik berbasis permainan tradisional dan scientific approach terhadap kemampuan berpikir kreatif. Cakrawala Pendidikan, 37(1), 71-84.

Muzdalipah, I., \& Yulianto, E. (2015). Pengembangan desain pembelajaran matematika untuk siswa SD berbasis aktivitas budaya dan permainan tradisional masyarakat kampung Naga. Jurnal Siliwangi, 1(1), 63-74.

Nugraha, Y. A., Handoyo, E., \& Sulistyorini, S. (2018). Traditional game on the social skill of students in the social science learning of elementary school. Journal of Primary Education, 7(2), 220-227. 
Nursyahidah, F., Saputro, B. A., \& Rubowo, M. R. (2018). Students problem solving ability based on realistic mathematics with ethnomathematics. Journal of Research and Advances in Mathematics education, 3(1), 13-24.

Rahmawati, N. D., Buchori, A., \& Bhihikmah. (2017). Pengembangan strategi permainan tradisioanl sunda manda pada pembelajaran matematika di SMP. Jurnal Ilmiah Pendidikan Matematika, 1(2), 165-172.

Rosa, M., \& Orey, D. C. (2011). Ethnomathematics: The cultural aspects of mathematics. Revista Latinoamericana Etnomatematicia, 4(2), 32-54.

Rusliah, N. (2016). Pendekatan etnomatematika dalam permainan tradisioanl anak di wilayah kerapatan Adat Koto Tengah Kota Sungai Penuh Propinsi Jambi. Proceedings of the International Conference on University-Community Engagement, (pp. 715-726).
Rusnilawati, Muthmainnah, H. T., Mufti, F. N., Istiqomah, Ulima, E. T., \& Hidayah, Y. M. (2018). Metode permainan tradisional engklek pada pembelajaran bangun datar menumbuhkembangkan motivasi belajar siswa. The 8th Yniversity Research Colloquium 2018 Universitas Muhammadiyah Purwekerto, (pp. 189-195).

Siregar, N., \& Lestari, W. (2018). Peranan permainan tradisional dalam mengembangkan kemampuan matematika Anak Usia Sekolah Dasar. Jurnal Mercumatika: Jurnal Penelitian Matematika dan Pendidikan Matematika, 2(2), 1-7.

Widodo, P., \& Lumintuarso, R. (2017). Pengembangan model permainan tradisional untuk membangun karakter pada siswa SD kelas atas. Jurnal Keolahragaan, 5(2), 183-193. 